https://helda.helsinki.fi

\title{
Life-history trait variation in a queen-size dimorphic ant
}

\section{Wolf, Jana I.}

2018-12

Wolf , J I , Punttila , P \& Seppä , P 2018 , ' Life-history trait variation in a queen-size

dimorphic ant ' , Ecological Entomology , vol. 43 , no. 6 , pp. 763-773 . https://doi.org/10.1111/een.12662

http://hdl.handle.net/10138/323997

https://doi.org/10.1111/een.12662

acceptedVersion

Downloaded from Helda, University of Helsinki institutional repository.

This is an electronic reprint of the original article.

This reprint may differ from the original in pagination and typographic detail.

Please cite the original version. 


\section{Life-history trait variation in a queen-size dimorphic ant}

2

3 Jana Irina Wolf ${ }^{1,2}$, Pekka Punttila ${ }^{3}$ and Perttu Seppä ${ }^{1,2,4}$

4

$5 \quad{ }^{1}$ Centre of Excellence in Biological Interactions, Organismal and Evolutionary Biology

6 Research Program, Faculty of Biological and Environmental Sciences, P.O. Box 65, FI-

700014 University of Helsinki, Finland

8

9 2Tvärminne Zoological Station, University of Helsinki J.A. Palménin tie 260, FI-10900

10 Hanko, Finland

11

$12{ }^{3}$ Finnish Environment Institute, P.O. Box 140, FI-00251, Helsinki, Finland 13

14

$15{ }^{4}$ Corresponding author: Organismal and Evolutionary Biology Research Program,

16 Faculty of Biological and Environmental Sciences, P.O. Box 65, FI-00014 University of 17 Helsinki, Finland, perttu.seppa@ helsinki.fi

18

19 Running title: Life-history variation in size-dimorphic ants 20 


\section{AbSTRACT}

22 1. Size polymorphism is often connected to alternative life-history traits, which may eventually lead to distinct size classes. In the ant Myrmica ruginodis, larger macrogyne and smaller microgyne queen morphs have been suggested to follow different reproductive strategies, which has presumably resulted in several differences in their

26 key life-history traits.

27 2. In this study, we examine the association of queen-size morphs with colony queen 28 number (monogyny vs. polygyny), dispersal and queen recruitment patterns as well as 29 habitat associations of the queen morphs. We do this by sampling established queens 30 from a large number of excavated nests from several populations, estimating genetic relatedness among coexisting queens and pitfall trapping free-ranging wingless queens.

32 3. Our results show that associations of queen morphs with colony queen number and nest-founding strategy holds only partly. The morph frequencies vary widely across

34 populations from practically pure macrogyne to more than $50 \%$ microgyne, but the expected association of macrogyne occurrence with monogyny and microgyne with polygyny is not universal. Dispersal and queen recruitment patterns also show that while most macrogynes participate in nuptial flights and most microgynes are recruited back to their natal nests, a fraction of both morphs use the alternative strategy.

4. Polygynous microgyne morph has been suggested to specialize in stable habitats, but our results from Finnish mesic heath forests do not support this. This study shows that other factors than just queen size also influence life-history trait variation and

42 reproductive strategies in ants.

44 Keywords: Ants, Habitat stability, Myrmica, Macrogyne, Microgyne, Size 


\section{INTRODUCTION}

Alternative reproductive strategies are a widely known phenomenon in the animal kingdom, and they are often associated with intraspecific size variation (Eberhard, 1980; Thornhill \& Alcock, 1983; Gross, 1985, 1996; Crespi, 1988; Danforth, 1991).

Size often strongly influences fitness, with larger individuals monopolising reproductive opportunities (Roff, 1992; Stearns, 1992). Alternatively, commonly occurring smaller ("sneaker") males seek reproductive opportunities alongside large, dominant and territorially behaving males (Eberhard, 1980; Thornhill \& Alcock, 1983; Gross, 1985; Crespi, 1988; Danforth, 1991). Size-dependent strategies can also be connected to dispersal (Dingle et al., 1980; Derr et al., 1981; Gonzaga \& Vasconcellos-Neto, 2001), where smaller individuals are usually assumed to be competitively inferior and thus disperse while larger ones behave philopatrically (Lawrence, 1987; Hanski et al., 1991). Nevertheless, this can also be reversed so that larger individuals disperse further than smaller conspecifics due to larger energy reserves (Anholt, 1990; O'Riain et al., 1996; Léna et al., 1998; Gundersen et al., 2002; Barbraud et al., 2003).

In ants, alternative reproductive strategies have been found especially in females, sometimes causing divergence in queen sizes and life-history strategies (Heinze \& Tsuji, 1995; Peeters \& Ito, 2001). Typically, queens in nests with only a single reproducing queen (monogyny) are larger than those in nests with many queens (polygyny) (see Peeters \& Ito, 2001). Large queens have larger glycogen and fat content than small queens, and they are also typically better equipped for dispersing by flight and independent nest founding (Passera \& Keller, 1990; Heinze \& Hölldobler, 1993; McInnes \& Tschinkel, 1995; Wheeler \& Martinez, 1995; Stille, 1996; Lachaud et al., 1999). Positive relatedness among coexisting queens in secondarily polygynous species suggests that new queens are often recruited to their natal nests (e.g. Crozier \& Pamilo, 1996). Colony propagation occurs then without dispersal by flying, via splitting of old nests (dependent colony founding), which might stay connected (budding) or not (fission) (Rosengren \& Pamilo, 1983; Hölldobler \& Wilson, 1990). Life-history traits in ants are often described as suites of linked characteristics centred around queen number (so-called polygyny syndrome, Rosengren \& Pamilo, 1983). 
The occurrence of polygyny in ants as an indicator of reduced dispersal has been associated with stability, patchiness and longevity of the habitat (Hölldobler \& Wilson, 1977; Rosengren \& Pamilo, 1983), as well as habitat crowding (Herbers, 1986). In stable habitats, patch size sets limits to the growth and propagation of nests through nest-site limitation, resource limitation and competition in general, selecting for increased polygyny (Hölldobler \& Wilson, 1977; Rosengren \& Pamilo, 1983; Herbers, 1986). If queen dispersal does not exceed further than the natal habitat patch and the number of nests that can co-occur in a given patch is restricted, such habitat patches are expected to become saturated with time with conspecific nests. In such a situation, the only possibility for newly produced queens to reproduce is to be recruited to an existing nest. Interspecific competition and high queen predation during colony founding can also make nest founding more difficult. Thus, both intra- and interspecific competition may reduce nest-founding opportunities, which increases dispersal risk and promotes queen philopatry (Greenwood, 1980) and recruitment.

Sometimes alternative reproductive strategies in ants lead to the emergence of queensize dimorphism, with either clearly separated or overlapping size distributions between the larger (macrogynes) and smaller (microgynes) queen morphs (Heinze \& Tsuji, 1995; Heinze \& Keller, 2000; Peeters \& Ito, 2001; Wolf \& Seppä, 2016a). Size morphs have been suggested to be associated with differences in life-history traits. Macrogyne queens supposedly disperse and are usually found in monogynous nests, which are founded independently after a nuptial flight (e.g. Elmes 1991; Rüppell \& Heinze 1999; Wolf \& Seppä 2016a). In contrast, microgyne queens do not usually join nuptial flights, as they are poorly equipped for both dispersal (Passera \& Keller, 1990; Heinze \& Hölldobler, 1993; Wheeler \& Martinez, 1995; Stille, 1996; Wolf \& Seppä, 2016b) and independent colony founding (McInnes \& Tschinkel, 1995; Peeters \& Ito, 2001). Instead, they presumably mate locally and seek adoption in secondarily polygynous nests instead. In ant genus Myrmica, there are two queen-size dimorphic species. The microgyne morph of M. rubra is a true inquiline parasite (Seifert 1993) currently speciating from its macrogynous host (e.g. Leppänen et al. 2015), whereas in M. ruginodis macrogynes and microgynes are free-living intraspecific queen morphs. The size distributions of the two morphs in $M$. ruginodis are overlapping, however, so that not all queens can be 
109 positively assigned to one of the morphs, and about one fourth of the polygynous nests

110 have a mixture of queen morphs (Elmes, 1991).

111 Since nest-founding strategies in queen-size dimorphic ants may differ depending on

112 habitat quality and patchiness (Lenoir et al., 2011), size morph frequencies are also

113 expected to differ across habitat types. For instance, in Temnothorax rugatulus,

114 microgynes have been suggested to profit from stable nesting substrate, such as rocky

115 outcrops, and to occur more often in high densities in those habitats, whereas

116 macrogynes are better colonisers than microgynes (Rüppell et al., 2001). Previous

117 suggestions about the association of $M$. ruginodis queen morphs with the habitat type

118 are somewhat contradictory. On one hand, Brian and Brian (1949) studied M. ruginodis

119 in English and Scottish moor habitats and suggested that macrogynes are predominant

120 in transitory habitats ("seral and mosaic cyclic vegetation types") and microgynes are

121 found in relatively stable habitats. On the other hand, our study habitat, boreal forest, is

122 a dynamic mosaic of different successional stages due to various disturbances

123 (Kuuluvainen, 2009; Kuuluvainen \& Aakala, 2011). In this type of landscape, nests in

124 early-successional habitats following recent disturbance are more polygynous than in

125 more stable late-successional habitats (Seppä et al., 1995). This suggests that the

126 polygynous microgyne morph specialises in rapidly changing early successional stages

127 rather than relatively stable old-growth habitats.

128 In this study, we investigated to what extent size morphs in the ant M. ruginodis are

129 associated with key life-history traits. For this purpose, we assessed queen-morph

130 identity and its association with i) number of established old queens in excavated

131 colonies, ii) queen dispersal patterns based on temporal distribution of free-ranging

132 wingless queens and iii) queen-recruitment patterns by estimating genetic relatedness

133 among co-existing queens separately in macrogyne and microgyne nests. Studying

134 multiple populations and complementing the results with previously published data

135 (Brian \& Brian, 1949; Elmes, 1991; Wolf \& Seppä 2016b) enabled us to assess the

136 spatial variation in the occurrence of the queen morphs and their association with

137 colony social structure, dispersal and colony founding patterns.

138 As suggested earlier (Brian \& Brian, 1949; Elmes, 1991), we expected to find a bimodal

139 queen-size distribution in M. ruginodis and that macrogyne and microgyne queens are 
140 generally found in monogynous and polygynous nests, respectively. Based on the close association of the colony queen number and other key life-history traits (Heinze \&

142 Tsuji, 1995; Peeters \& Ito, 2001), we also expect to find that macrogyne queens are

143 more prone to dispersing by flight than microgyne queens. This is expected to show in

144 the pitfall data as an excess of free-ranging wingless macrogyne queens after the nuptial

145 flight and more even distribution of wingless microgynes across the season.

146 Furthermore, we expected to find that coexisting microgyne queens are related, which

147 would indicate that they disperse locally and are recruited back to their natal nests. The

148 exact prediction of queen relatedness in macrogynes is not clear, because macrogyne

149 queens are rarely expected to reside in polygynous nests. Finally, we analyse habitat

150 association of free-ranging wingless queens and test earlier hypotheses (see above)

151 about the occurrence of the monogynous (macrogyne) and polygynous (microgyne)

152 morphs.

154 MATERIAL AND MeTHODS

\section{Sampling}

156 We sampled established old queens by carefully excavating whole nests using

157 previously established procedures (e.g. Seppä 1994; Walin \& Seppä 2001) at three sites

158 in southern Finland, i) Savero (Kouvola) in 1992; ii) Antby (Raasepori) in 2004 and iii)

159 TV/Leimann (Hanko). TV/Leimann population was sampled three times, first in 1994

160 for another study (Walin \& Seppä 2001) and again in 2012 and 2014 (combined as

161 TV/Leimann 2010s). Details of excavated populations and sampling are given in Table

1621 and Appendix S1.

163 We also used pitfall-trap data of free-ranging wingless queens collected at two sites. In

164 Musturi old-growth forest (Ruovesi, 1985), the sampling covered a 1.3 ha plot in a

165 spruce-dominated old-growth reserve (Niemelä et al. 1989). In Multiharju (Seitseminen

166 National Park, Ikaalinen, 1986), the sampling covered a $1.4 \mathrm{~km}$ transect consisting of a

167 mixture of mostly old forest and forested mire types (Niemelä et al. 1992), with seven

168 habitat types distinguished for the present study. For both sampling areas, the traps were

169 under operation for most of the snow-free season, which we divided into three periods.

170 Period I started in the early spring after the snowmelt and ended in mid-July before the 
171 M. ruginodis nuptial flight. Period II covered the nuptial flight period, ending in mid-

172 August and period III after that until late autumn. Details of sampled populations and

173 sampling schemes are given in Table 1 and Appendix S1.

174 Finally, we also used queen data from two earlier excavation studies, one where the data

175 were collected mostly from Scotland (hereafter Scotland, Brian \& Brian, 1949) and

176 another where the data were collected from southern England (Elmes, 1991) as a

177 comparison to the Finnish data.

\section{Morphometrics}

179 Until 2004, we measured the head width of queens directly under a binocular to 0.02

$180 \mathrm{~mm}$ accuracy. For the more recent excavations, we first photographed the sampled

181 individuals with a Canon EOS 50D camera at a 25× magnification. Then we measured

182 the head width of queens with the software ImageJ (Abràmoff et al., 2004) to $0.02 \mathrm{~mm}$

183 accuracy. High repeatability of this method has been shown previously (Wolf \& Seppä,

184 2016b). By optimising a bimodal fit to the queen-size distribution, head width of 1.065

$185 \mathrm{~mm}$ was earlier determined as a cut-off to separate microgynes and macrogynes (Elmes,

186 1991). Later, this was shown to be in good accordance with a behavioural cut-off value

187 based on the differential participation of queens of different size morphs in the nuptial

188 flight in TV/Leimann population sampled in 2013 (Wolf \& Seppä, 2016b). We divided

189 nests to macrogynous, microgynous and mixed nests, or - for some analyses - assigned

190 mixed nests based on their predominant morph type (median queen size in microgynes

$191 \leq 1.06 \mathrm{~mm})$.

\section{Statistical analysis}

194 In each population, we tested queen-size distributions for normality with Kolmogorov-

195 Smirnov tests and for modality with Sarle's bimodality coefficient (BC, SAS Institute

196 Inc, 1990). BC is calculated as a ratio of squared skewness and kurtosis of the size

197 distribution, corrected for the sample size. The BC of a uniform distribution gets a value

$198 \mathrm{BC}=0.56$, while higher values indicate bimodality and lower ones unimodality (SAS

199 Institute Inc, 1990). We tested whether the queen-size distributions in the TV/Leimann

200 population sampled c. 20 years apart were similar with two-sample Kolmogorov-

201 Smirnov-test. We also tested if queens from monogynous nests were larger than queens 
202 from polygynous nests by fitting a linear mixed model to the data with

203 monogyny/polygyny as a fixed factor and populations and nests nested into populations

204 as random factors (Finnish populations only).

205 We used log-likelihood ratio tests ( $G$ test) to test the variation in queen number across

206 populations by testing the difference in frequencies of queenless, monogynous and

207 polygynous nests, and to test the variation in morph occurrence in macrogynous,

208 microgynous and mixed nests across populations. We explored the association of size

209 morphs with the level of polygyny (monogyny/polygyny) in the nests first in general by

210 using log-likelihood ratio tests. Then we used binomial tests to assess if macrogynes

211 and microgynes occurred more often than randomly in monogynous and polygynous

212 nests, respectively, and if monogynous and polygynous nests had more often than

213 randomly macrogynes and microgynes, respectively. Furthermore, we explored the

214 association of the queen number with queen size by calculating Spearman rank

215 correlation between queen number and mean queen size in nests (Finnish and S-English

216 populations) and fitted a linear mixed model to the data to test the relationship between

217 the proportion of microgynes and the number of queens in a nest was tested with the

218 proportion microgynes as a fixed factor and populations as a random factor (Finnish

219 populations only).

220 For the pitfall-trap data, we tested whether the free-ranging queens were distributed

221 randomly among the sampling periods and habitat types (Multiharju only) using log-

222 likelihood ratio test, calculating the expected occurrence rates based on the distribution

223 of sampling effort among the habitat types and sampling periods. We also used log-

224 likelihood ratio test to test whether the occurrence of macrogynes and microgynes was

225 similar among the habitat types and sampling periods. We used SPSS 25.0 (IBM Corp.

226 Released 2017) and Statistix 9.0 (Analytical Software 1985-2008) for the analyses.

\section{Genetic analyses}

229 The samples from 1990's (Savero, TV/Leimann 1994) were analysed with standard

230 horizontal starch-gel electrophoresis. Genetic variation was resolved in four allozyme

231 loci: $\alpha$-glycerophosphate dehydrogenase-1 (aGpdh-1), peptidase (Pep, substrate: 
232 glycyl-L-leucine), phosphoglycerate kinase (Pgk), and esterase-2 (Est-2, substrate: 4methylumbelliferyl acetate) with protocols described in Seppä (1992).

234 We tested 21 microsatellite primers previously developed for other Myrmica species

235 (Evans, 1993; Herbers \& Mouser, 1998; Henrich et al., 2003; Azuma et al., 2005;

236 Zeisset et al., 2005). Twelve of these were polymorphic and amplified reliably in PCR

237 in M. ruginodis, and we used them for samples from TV/Leimann 2010s. PCR products

238 were analysed with an ABI 3730 sequencer and alleles scored using GeneMapper

239 version 5 (Applied Biosystems). Details of DNA extraction, primer testing and PCR

240 conditions are given in Appendix S2.

241 We tested queen recruitment pattern in three populations (Savero, TV/Leimann, 1994

242 and TV/Leimann 2010s) by estimating genetic relatedness among coexisting queens

243 with the software RELATEDNESS 5.0.4. (Queller \& Goodnight, 1989). We estimated

244 the overall relatedness for the whole data and separately in macrogyne and microgyne

245 nests and used t-tests to test whether relatedness estimates were significantly different

246 from each other. In the analysis, we added the queens from monogynous nests in the

247 data to calculate the background allele frequencies and jackknifed the estimates over

248 loci and nests for standard errors.

250 RESULTS

\section{Nest excavations and queen number}

252 Between 32 and 132 entire nests were excavated in the six study populations (including 253 the reference populations in the UK, Table 1). In Myrmica, a substantial proportion of 254 nests are queenless (Elmes \& Keller, 1993). In our populations, roughly one third of the 255 nests were queenless, one third monogynous and one third polygynous, but the 256 proportions of these categories varied widely and significantly across populations

257 (Table 2; $\mathrm{G}=42.2$, $\mathrm{df}=8, \mathrm{P}<0.001$ ). When regarding queenless nests as monogynous, 258 the average estimated queen number in our populations varied between 1.03 and 3.91.

259 [Previous genetic studies have shown that practically all queenless nests had been 260 monogynous before losing their queen and the observed queen number (one vs. many) 261 is a good proxy for the number of egg-layers in the nests (Seppä, 1994; Walin \& Seppä, 262 2001)]. Disregarding the Antby population with only a single polygynous nest (3\%), the 
263

264

265

266

\section{Queen-size distribution}

268 Queen size was normally distributed only in one of our study populations. In the rest of 269

proportion of polygynous nests varied from 35\% (Savero) to 60\% (TV/Leimann, 1994), but the average queen number in polygynous nests varied only from four (S-England) to six (TV/Leimann, Table 2). the populations, queen-size distribution was non-normal and negatively skewed in six of eight populations and size distributions were uniform or bimodal $(\mathrm{BC} \geq 0.56)$ or nearly so in three populations (Fig. 1, 2, Table 3; Appendix S3, S4). In monogynous nests, queen sizes were non-normally distributed in half of the populations, but in all populations in polygynous nests (Table 2). Queen-size distributions in the TV/Leimann population sampled c. 20 years apart were similar (Table 3, Fig. 1, two-sample Kolmogorov-Smirnov-test, $\mathrm{P}=0.22$ ).

In general, queens in the monogynous nests were significantly larger than in the polygynous nests (linear mixed model, $\mathrm{F}=11.73 \mathrm{df}=90.88, \mathrm{P}=0.001$ ). The maximum queen size was similar in all populations $(1.18-1.20 \mathrm{~mm})$, but queen-size ranges varied across populations. The size range was largest in TV/Leimann and Multiharju (minimum queen size $0.84 \mathrm{~mm}$ ) and smallest in predominantly macrogynous populations (Antby, Musturi, Savero; minimum $0.98 \mathrm{~mm}$ ). In both TV/Leimann data sets, the smallest queens were sampled from two highly polygynous nests and constituted a majority of queens in those nests (Appendix S3).

\section{Queen-number association with the size morphs}

The frequency of microgyne queens in excavated populations ranged from c. $25 \%$ to c. $65 \%$ (Table 2). The frequency of mixed nests (polygynous nests that had queens of both size morphs) ranged from zero to $50 \%$ of the polygynous nests (Table 2), and the proportions of nest types (pure macrogyne nests, pure microgyne nests, mixed nests) varied significantly across populations (Table $2, \mathrm{G}=26.82$, $\mathrm{df}=8, \mathrm{P}<0.001$ ). In the pitfall-trap data sets, 10 and $30 \%$ of queens were microgynes. 
292 At the population level, queen morphs were not distributed randomly to monogynous

293 and polygynous nests (Table 2, Finnish populations combined, $\mathrm{G}=14.4$, df $=1, \mathrm{P}<$

294 0.001). Microgynes occurred significantly more often in polygynous than monogynous

295 nests (binomial test, $\mathrm{P}<0.001$ ), but there was no significant difference in macrogyne

296 occurrence in monogynous and polygynous nests (binomial test, $\mathrm{P}=0.072$ ).

297 Furthermore, monogynous nests had significantly more often macrogynes than

298 microgynes (binomial test, $\mathrm{P}<0.001$ ), but there was no significant difference in morph

299 occurrence in polygynous nests (binomial test, $\mathrm{P}=0.082$ ).

300 At the nest level, we found a significant positive association when comparing the

301 proportion of microgynes with the number of queens (Finnish populations combined,

302 linear mixed model, $\mathrm{F}=9.54, \mathrm{df}=129.00, \mathrm{P}=0.002$ ). Queen number and mean queen

303 size in the nests were also significantly negatively correlated in both Finnish and S-

304 English populations (Spearman rank correlation; all Finnish samples combined: $r_{\mathrm{s}}=$ -

$3050.39, \mathrm{P}<0.001, \mathrm{~N}=131 ; \mathrm{S}$-England: $\mathrm{r}_{\mathrm{s}}=-0.55, \mathrm{P}<0.001, \mathrm{~N}=79$ ).

306

307 Distribution of free-ranging wingless queens within season and across habitats

308 All queens sampled by pitfall trapping were wingless. In both pitfall data sets, the

309 occurrence of $M$. ruginodis queens across the three sampling periods (before, during and

310 after the nuptial flight) was non-random (Fig. 3, Appendix S4, Musturi: G=17.5, df =

3112 2, $<$ 0.001; Multiharju: $\mathrm{G}=8.2, \mathrm{df}=2, \mathrm{p}<0.05$ ). Period before the nuptial flight

312 (Period I) in both Musturi and Multiharju had the highest cell contributions (deficiency

313 of gynes in Musturi, excess of gynes in Multiharju) to the test statistics. Distribution of

314 macrogynes and microgynes was similar across the sampling periods in both data sets

315 (Fig. 3, Appendix S4, Musturi: $\mathrm{G}=0.87, \mathrm{df}=2, \mathrm{P}=0.65$; Multiharju: $\mathrm{G}=0.65$, $\mathrm{df}=2$,

$316 P=0.69)$.

317 In Multiharju, there was a significant difference in the occurrence rate of queens across

318 habitats (Fig. 4, $\mathrm{G}=34.2, \mathrm{df}=6, \mathrm{P}<0.001$ ), with old spruce-pine mire (habitat type 5)

319 showing the largest cell contribution (excess of queens compared to the random

320 expectation) and old spruce-dominated mesic heath forest (habitat type 4) the next

321 largest contribution (deficiency of queens) to the test statistics. However, the queen- 
322

323

324

325

326

327

328

329

330

331

332

333

334

335

336

337

338

339

340

341

342

343

344

345

346

347

348

349

350

morph distributions across the habitat types did not differ significantly from each other (Fig. 4, Appendix S4, $\mathrm{G}=10.7$, df = 6, $\mathrm{P}=0.099$ ).

\section{Genetic relatedness among queen nest mates}

Average relatedness among queen nest mates was similar in all three populations where genetic data were available (Table 4, Savero vs. TV/Leimann 1994, t-test, $\mathrm{t}=0.85$, df $=$ $39, \mathrm{P}=0.40$; statistical differences to TV/Leimann 2010s population were not tested because the genetic marker used was different). When estimated separately for polygynous macrogyne and microgyne nests, relatedness in macrogyne nests was significantly lower than relatedness in microgyne nests in one population (TV/Leimann 1994: $\mathrm{t}=4.10, \mathrm{df}=19, \mathrm{P}<0.001$ ), but not in two others (Savero: $\mathrm{t}=0.26, \mathrm{df}=18, \mathrm{P}=$ 0.80; TV/Leimann 2010s: $\mathrm{t}=0.84, \mathrm{df}=32, \mathrm{P}=0.41$ ).

\section{DISCUSSION}

Alternative reproductive strategies associated with intraspecific size variation are common (e.g. Eberhard, 1980; Thornhill \& Alcock, 1983; Gross, 1985, 1996; Crespi, 1988; Danforth, 1991) and in ants they are usually manifested only in females (Heinze \& Tsuji, 1995; Peeters \& Ito, 2001). Our work shows that the queen-size morphs in the ant Myrmica ruginodis are associated with key life-history traits, such as queen number, dispersal and queen recruitment, but the association is not universal and particularly the number of queens in the nests can be extremely flexible.

Large variation in queen number within and across study populations is in line with previous studies on many facultatively polygynous ants, including other Myrmica sp. (e.g. Elmes \& Keller, 1993; Crozier \& Pamilo, 1996; Pamilo et al 1997; Sundström et al., 2005). Queen number can also vary temporally within single Myrmica populations (Elmes, 1987; Elmes \& Petal, 1990) due to the irregular gyne production in the nests (Elmes, 1973; Elmes \& Petal, 1990). The occurrence of queenless nests (up to 50\%) is due to the fast queen turnover in Myrmica, which often leaves nests queenless after the demise of the queen(s), particularly when the queen number is low (Seppä, 1994, Evans, 
351

352

353

354

355

356

357

358

359

360

361

362

363

364

365

366

367

368

369

370

371

372

373

374

375

376

377

378

379

380

1996). This also emphasises queen number as an unusually flexible trait in Myrmica ants (Elmes \& Keller, 1993).

\section{Queen morph - queen number association}

Queen size was normally distributed only in one of our study populations (Antby), which results from this largely monogynous population being dominated by a single queen morph (macrogynes). In the rest of the populations, the actual size ranges and the non-normal, negatively skewed or bimodal queen-size distributions suggest that they are a mixture of both queen morphs (Figures 1-2, Appendices S3-4), and that the frequency of the morphs varies widely across the populations. Considering that previous work has described M. ruginodis as a size-dimorphic species (Brian \& Brian, 1949, 1955; Elmes, 1991), finding a strongly macrogyne-dominated population with a normal queen-size distribution is unexpected. Morph frequencies and social structure vary extensively among nests and among (sub)populations also in two other queen-size dimorphic ants, Temnothorax rugatulus (Rüppell et al., 1998, 2001) and Ectatomma ruidum (Chantal Poteaux, pers. communication).

Queen number was associated with the occurrence of the size morphs in M. ruginodis, but not in all populations. The proportion of microgynes and the number of queens in the nest were positively correlated and the average queen size in nest decreased with increasing queen number, which is common in many polygynous ants (e.g. Formica truncorum, Sundström, 1995; F. selysi, Meunier \& Chapuisat, 2009). Furthermore, macrogynes were associated with monogyny and microgynes with polygyny more often than randomly, but all associations were not significant. All these indicate that there is at least an indirect link in $M$. ruginodis between the level of polygyny and the frequency of microgynes. However, in one study population (Savero), the majority of macrogynes and microgynes were found in polygynous and monogynous nests, respectively (Table 2), which is reversed compared to the expected. This suggests that queen number as a plastic trait is also affected by other factors than morph frequencies in M. ruginodis. Definite conclusions based on Savero population are difficult to draw, however, because the number of microgynes found is small. 
381 Queen dispersal and recruitment

382 Seasonal distribution of free-ranging wingless queens caught by pitfall-trapping was not random within the study populations, but the distributions of macrogynes and microgynes caught in the same populations were similar. Thus, our result does not support our prediction of different dispersal patterns in populations with different proportions of microgynes. In the macrogyne dominated Musturi population, we expected to find an excess of free-ranging wingless queens directly after the nuptial flight (period III), but we only found a deficiency of queens during period I (from the start of the season until nuptial flights; Fig. 3, Appendix S4). As microgyne queens are expected to move outside their nests more actively than macrogynes due to commonly occurring dependent colony founding in polygynous ants, we expected to find a more even distribution of free-ranging queens across the season in Multiharju with a relatively large proportion of microgynes. Instead, there was an excess of queens caught

394 from Multiharju only during period I (Fig. 3, Appendix S4).

395 In accordance with previous results (Seppä, 1994), coexisting queens are related in 396 polygynous nests on average, which indicates that nests must have recruited their own 397 daughters as new queens. Previous dispersal experiments in the TV/Leimann population 398 revealed that most $M$. ruginodis microgynes do not join mating swarms, i.e. they do not 399 disperse by flight (Wolf \& Seppä, 2016b). Instead, they probably mate in the vicinity of

400 their natal nest and high relatedness among coexisting microgyne queens corroborates

401 that many microgynes are recruited back to their natal nest. Our relatedness results show 402 that the recruitment process in macrogynes is at least partly different, as coexisting 403 macrogyne queens were not related at all in TV/Leimann 1994 data. However, 404 relatedness among coexisting macrogynes in polygynous nests is difficult to predict 405 since most macrogynes join a mating swarm-(Wolf \& Seppä 2016b) and presumably 406 later found new monogynous colonies independently.

407 If a macrogyne queen first joins a nuptial flight, she has three alternatives that would 408 result in high queen relatedness in a polygynous nest: she can i) return to her natal nest 409 after leaving the mating swarm; ii) found a new nest independently with related queens 410 or iii) seek adoption in a random nest simultaneously with other related queens. All 411 these alternatives are unlikely, however. M. ruginodis mating flights are rather extensive 
412 and attract winged sexuals from a large number of nests from a relatively large area

413 (Brian \& Brian, 1949; Elmes, 1991; Wolf \& Seppä, 2016b, unpublished observations).

414 Orientation of flying $M$. ruginodis queens has not been studied, but returning to the 415 natal nest from a distant nuptial flight site seems unlikely. Furthermore, pleometrosis,

416 independent nest founding by a group of queens, has never been reported in $M$.

417 ruginodis and related queens seeking entrance to the same non-natal nest must be rare.

418 However, queen relatedness patterns in both microgyne and macrogyne nests suggests

419 that not all queens follow the queen-dispersal dichotomy suggested - long-range

420 dispersal of macrogynes by flight and local dispersal of microgynes by foot (Wolf \&

421 Seppä, 2016b), and that part can be large enough to change the relatedness regime in the 422 nests. On one hand, positive relatedness in macrogyne nests must be caused by some 423 macrogynes forgoing the nuptial flight and joining their natal nests afterwards. On the 424 other hand, relatedness is rather variable across microgyne nests in TV/Leimann 2010s 425 and Savero populations based on the large standard errors (Table 4), suggesting that 426 nests recruit both their own daughters and unrelated queens.

\section{Habitat association of free-ranging M. ruginodis queens}

429 Our results on the distribution of free-ranging wingless queens showed that queens 430 sampled were non-randomly distributed across different habitat types, but that there was 431 no difference in how queen morphs were distributed. Thus, our results do not support 432 the hypothesis that $M$. ruginodis microgynes specialise in stable habitats in successional 433 boreal forests.

434 Apart from habitat stability, differences in microclimate, such as shadiness, moisture 435 and presence of competitors may have a strong influence on the morph occurrence. 436 Although the moor sites in the UK studied by Elmes $(1978,1991)$ ranged from dry to 437 very wet, the common feature and major difference to the Finnish sites is presumably 438 the lack of shadiness (absence of trees) in English populations, as most of the English 439 sampling sites were covered by lower plants only (grass, herbs, dwarf shrubs etc). This 440 lower vegetation will generally offer more sun-exposed habitats, especially when 441 grazing animals maintain them relatively open (Elmes, 1978). Myrmica ruginodis is the 442 least thermophile of all the Myrmica species (Radchenko \& Elmes, 2010) and capable 
443 of inhabiting also closed-canopy forests (e.g. Punttila et al., 1991, 1994, 2016, Niemelä

444 et al. 1996). Most of our study areas were mesic forests and thus generally rather shady.

445 Thus, a combination of habitat stability and amicable microclimate (lack of closed tree

446 canopy) could in general explain the higher occurrence of the microgyne morph in the

447 UK (c. 70\%) compared to the North-European boreal forests (c. 10-50\%). In the former

448 habitat type, selection for good dispersal ability is relaxed, which is expected to favour

449 the less-dispersive microgyne morph. This could be tested by studying spatial

450 population structure in the two areas.

451 Boreal mesic heath forests undergo a continuous successional change and cannot be

452 described as stable, with perhaps the slowly changing old-growth stage as the only

453 exception (Kuuluvainen, 2009; Kuuluvainen \& Aakala, 2011). Thus, habitat stability as

454 such cannot be used as a direct predictor of microgyne occurrence in boreal forests, as

455 suggested by Brian \& Brian (1949) for the moor habitats in the UK. An earlier genetic

456 study on M. ruginodis in successional boreal forests also contrasts the habitat stability

457 hypothesis (Seppä et al., 1995): On one hand, worker nestmate relatedness, a proxy for

458 the level of polygyny and thus for the frequency of microgyne morph, was lowest in the

459 young forest patches following disturbance (clearcutting, sometimes combined with

460 prescribed burning). On the other hand, the population sampled from an old-growth

461 forest that could be considered the most stable habitat compared to the rest of the

462 populations is practically monogynous, suggesting the absence of microgynes (Seppä et

463 al., 1995).

464

\section{Conclusions}

466 Our study, together with our previous results (Wolf \& Seppä, 2016), partly confirms the 467 association of queen-size morphs with key life-history traits in the ant Myrmica 468 ruginodis, but the association is not straightforward and universal, with individual 469 populations showing even reversed associations. Particularly the queen number is an 470 unusually plastic trait in Myrmica ants (e.g. Elmes \& Keller 1993), which evidently 471 applies also separately to the size morphs of $M$. ruginodis. Indeed, the conventional 472 dichotomy to monogynous and polygynous ants with associated distinct life-history 473 traits seems as a simplification. In reality, many ants are facultatively polygynous and 
474 life-history traits are neither simple binary traits nor associated with only a single social

475 colony structure. Especially, a critical distinction in queen number concerning queen

476 dispersal and subsequent nest-founding patterns does not seem to be the transition from

477 monogyny to polygyny, but from facultatively to obligatory polygyny (Sundström et al.,

478 2005; Boomsma et al., 2014).

479

480 ACKNOWLEDGEMENTS

481 This work was funded by the Academy of Finland (Centre of Excellence in Biological

482 Interactions, grant no. 251337 and 284666). We thank Heini Ali-Kovero, Yrjö Haila,

483 Eero Halme, Markus Haveri, Jari Niemelä, Cia Olsson, Timo Pajunen, Harri Tukia and

484 Laura Walin for help in the field and the lab, Sanja Hakala for help with statistical

485 analyses, and Heikki Helanterä, David Nash, Pekka Pamilo and anonymous reviewers

486 for comments on the manuscript.

487

488 CONTRIBUTION OF AUTHORS

489 All authors contributed to the project design, data collection and analysis, and paper

490 writing.

491

492 SUPPORTING INFORMATION

493 Appendix S1: Sampling Scheme

494 Appendix S2: Laboratory protocols for DNA extraction and DNA microsatellite

495 analysis

496 Appendix S3: Queen size data, excavated nests

497 Appendix S4: Queen size data, pitfall data

498 
499

500

501

502

503

504

505

506

507

508

509

510

511

512

513

514

515

516

517

518

519

520

521

522

523

524

525

526

527 morphometrics, and behavioral basis of a fighter-flier polymorphism in male 528 Hoplothrips karnyi (Insecta: Thysanoptera). Behavioral Ecology and Sociobiology, 529 23, 93-104. doi: 10.1007/bf00299892

\section{REFERENCES}

Abràmoff, M.D., Magalhães, P.J. \& Ram SJ (2004) Image processing with ImageJ. Biophotonics International, 11, 36-42.

Analytical Software (1985-2008) Statistix 9. Tallahassee FL, USA.

Anholt, B.R. (1990) Size-biased dispersal prior to breeding in a damselfly, Oecologia

$$
\text { 83, 385-387. doi: 10.1007/BF00317564 }
$$

Azuma, N., Takahashi, J., Kikuchi, T., Yoshimura, M., Onoyama, K. \& Higashi S (2005) Microsatellite loci for Myrmica kotokui and their application in some congeneric ant species distributed in northern Japan, Molecular Ecology Notes $\mathbf{5}$, 118-120. doi: 10.1111/j.1471-8286.2004.00849.x

Barbraud, C., Johnson, A.R. \& Bertault, G. (2003) Phenotypic correlates of postfledging dispersal in a populations of greater flamingos: the importance of body condition. Journal of Animal Ecology, 72, 246-257. doi: 10.1046/j.1365-

$$
\text { 2656.2003.00695.x }
$$

Boomsma, J.J., Huszár, D.B. \& Pedersen, J.S. (2014) The evolution of multiqueen breeding in eusocial lineages with permanent physically differentiated castes. Animal Behavior, 92, 241-252.

Brian, M.V. \& Brian, A.D. (1949) Observations on the taxonomy of the ants Myrmica rubra L. and M. laevinodis Nylander (Hymenoptera: Formicidae). Transactions of the Royal Entomological Society of London, 100, 393-409. doi: 10.1111/j.1365-

$$
\text { 2311.1949.tb01423.x }
$$

Brian, M.V. \& Brian, A.D. (1955) On the two forms macrogyna and microgyna of the ant Myrmica rubra L. Evolution, 9, 280-290. doi 10.2307/2405649

Cajander, A.K. (1949) Forest types and their significance. Acta Forestalia Fennica, 56, 21-38

Collingwood, C.A. (1979) The Formicidae (Hymenoptera) of Fennoscandia and Denmark. Scandinavian Science Press Ltd, Klampenborg, Denmark.

Crespi, B.J. (1988) Adaptation, compromise, and constraint: the development, 
530 Crozier, R.H. \& Pamilo, P. (1996) Evolution of social insect colonies: sex allocation and kin selection. Oxford University Press, Oxford, U.K.

Czechowski, W., Radchenko, A., Czechowska, W. \& Vepsäläinen, K. (2012) The ants of Poland with reference to the myrmecofauna of Europe. Fauna Poloniae, 4, 1-496.

Danforth, B.N. (1991) The morphology and behavior of dimorphic males in Perdita portalis (Hymenoptera: Andrenidae). Behavioral Ecology and Sociobiology, 29, 235247. doi: $10.1007 / \mathrm{bf00163980}$

Derr, J.A., Alden, B. \& Dingle, H. (1981) Insect life histories in relation to migration, body size, and host plant array: a comparative study of Dysdercus. Journal of Animal Ecology, 50, 181-194 doi: 10.2307/4039

Dingle, H., Blakley, N.R. \& Miller, E.R. (1980) Variation in body size and flight performance in milkweed bugs (Oncopeltus). Evolution, 34, 371-385. doi: $10.2307 / 2407400$

Eberhard, W.G. (1980) Horned beetles. Scientific American, 242, 166-182. doi: 10.1038/scientificamerican0380-166

Elmes, G.W. (1973) Observations on the density of queens in natural colonies of Myrmica rubra L. (Hymenoptera: Formicidae). Journal of Animal Ecology, 42, 761771. doi: $10.2307 / 3136$

Elmes, G.W. (1976) Some observations on the microgyne form of Myrmica rubra L. (Hymenoptera, Formicidae). Insect Sociaux, 21, 3-22 doi: 10.1007/BF02283902

Elmes, G.W. (1978) Populations of Myrmica (Formicidae) living on different types of Calluna moorland - a semi-natural habitat of Southern England. Memorabilia Zoologica, 29, 41-60

Elmes, G.W. (1987) Temporal variation in colony populations of the ant Myrmica sulcinodis: I. Changes in queen number, worker number and spring production. Journal of Animal Ecology, 56, 559-571. doi: 10.2307/5068

Elmes, G.W. (1991) Mating strategy and isolation between the two forms, macrogyna and microgyna, of Myrmica ruginodis (Hym. Formicidae). Ecological Entomology, 16, 411-423. doi: 10.1111/j.1365-2311.1991.tb00234.x 
562 Elmes, G.W. \& Keller, L. (1993) Distribution and ecology of queen number in ants of

563

564

565

566

567

568

569

570

571

572

573

574

575

576

577

578

579

580

581

582

583

584

585

586

587

588

589

590

591 the genus Myrmica. Queen number and Sociality in Insects (ed. by L. Keller), pp. 294-307. Oxford University Press, Oxford, U.K.

Evans, J.D. (1993) Parentage analyses in ant colonies using simple sequence repeat loci. Molecular Ecology, 2:393-397 doi: 10.1111/j.1365-294x.1993.tb00032.x

Evans, J.D. (1996) Queen longevity, queen adoption, and posthumous indirect fitness in the facultatively polygynous ant Myrmica tahoensis. Behavioral Ecology and Sociobiology 39, 275-284. doi: 10.1007/s002650050290

Gonzaga, M.D.O. \& Vasconcellos-Neto, J. (2001) Female body size, fecundity parameters and foundation of new colonies in Anelosimus jabaquara (Araneae, Theridiidae). Insectes Sociaux, 48, 94-100. doi: 10.1007/p100001765

Gross, M.R. (1985) Disruptive selection for alternative life histories in salmon. Nature, 313, 47-48 doi: 10.1038/313047a0

Gross, M.R. (1996) Alternative reproductive strategies and tactics: diversity within sexes. Trends in Ecology and Evolution, 11, 92-98. doi: 10.1016/01695347(96)81050-0

Greenwood, P.J. (1980) Mating systems, philopatry and dispersal in birds and mammals. Animal Behavior, 28, 1140-1162. doi: 10.1016/s0003-3472(80)80103-5

Gundersen, G., Andreassen, H.P. \& Ims, R.A. (2002) Individual and population level determinants of immigration success on local habitat patches: an experimental approach. Ecology Letters, 5, 294-301. doi: 10.1046/j.1461-0248.2002.00320.x

Hanski, I., Peltonen, A. \& Kaski, L. (1991) Natal dispersal and social dominance in the common shrew Sorex araneus. Oikos, 62, 48-58. doi: 10.2307/3545445

Heinze, J. \& Hölldobler, B. (1993) Queen polymorphism in an Australian weaver ant, Polyrachis cf. doddi. Psyche, 100, 83-92. doi: 10.1155/1993/47808

Heinze, J. \& Keller, L. (2000) Alternative reproductive strategies: a queen perspective in ants. Trends in Ecology and Evolution, 15, 508-512. doi: 10.1016/s01695347(00)01995-9

Heinze, J. \& Tsuji, K. (1995) Ant reproductive strategies. Researches on Population Ecology, 37, 135-149. doi: 10.1007/bf02515814 
592 Henrich, K.O., Sander, A.C., Wolters, V. \& Dauber, J. (2003) Isolation and

593

594

595

596

597

598

599

600

601

602

603

604

605

606

607

608

609

610

611

612

613

614

615

616

617

618

619

620

621 characterization of microsatellite loci in the ant Myrmica scabrinodis. Molecular Ecology Notes, 3, 304-306. doi: 10.1046/j.1471-8286.2003.00433.x

Herbers, J.M. (1986) Nest site limitation and facultative polygyny in the ant Leptothorax longispinosus. Behavioral Ecology and Sociobiology, 19, 115-122. doi: 10.1007/bf00299946

Herbers, J.M. (1993) Ecological determinants of queen number in ants. Queen number and Sociality in Insects (ed. by L. Keller), pp. 262-293. Oxford University Press, Oxford, U.K.

Herbers, J.M. \& Mouser, R.L. (1998) Microsatellite DNA markers reveal details of social structure in forest ants. Molecular Ecology, 7, 299-306. doi: 10.1046/j.1365294x.1998.00349.x

Hölldobler, B. \& Wilson, E.O. (1977) The number of queens: an important trait in ant evolution. Naturwissenschaften, 64, 8-15. doi: 10.1007/bf00439886

Hölldobler, B. \& Wilson, E.O. (1990) The ants. Springer-Verlag, Berlin.

IBM Corp. Released 2017. IBM SPSS Statistics for Windows, Version 25.0. Armonk, NY: IBM Corp.

Keller, L. (1995) Social life: the paradox of multiple-queen colonies. Trends in Ecology and Evolution, 10, 355-360. doi: 10.1016/s0169-5347(00)89133-8

Kuuluvainen, T. (2009) Forest management and biodiversity conservation based on natural ecosystem dynamics in Northern Europe: The complexity challenge. Ambio, 38, 309-315. doi: 10.1579/08-a-490.1

Kuuluvainen, T. \& Aakala, T. (2011) Natural forest dynamics in boreal Fennoscandia: a review and classification. Silva Fennica, 45, 823-841. doi: 10.14214/sf.73

Lachaud, J.P., Cadena, A., Schatz, B., Pérez-Lachaud, G. \& Ibarra-Núñez, G. (1999)

Queen dimorphism and reproductive capacity in the ponerine ant, Ectatomma ruidum Roger. Oecologia, 120, 515-523. doi: 10.1007/s004420050885

Lawrence, W.S. (1987) Dispersal: an alternative mating tactic conditional on sex ratio and body size. Behavioral Ecology and Sociobiology, 21, 367-373. doi: $10.1007 / \mathrm{bf00299931}$ 
622 Léna, J.P., Clobert, J., De Fraipont, M., Lecomte, J. \& Guyot, G. (1998) The relative

623

624

625

626

627

628

629

630

631

632

633

634

635

636

637

638

639

640

641

642

643

644

645

646

647

648

649

650

651

652 influence of density and kinship on dispersal in the common lizard. Behavioral Ecology, 9, 500-507. doi: 10.1093/beheco/9.5.500

Lenoir, J.C., Lachaud, J.P., Nettel, A., Fresneau, D. \& Poteaux, C. (2011) The role of microgynes in the reproductive strategy of the neotropical ant Ectatomma ruidum. Naturwissenschaften, 98, 347-356. doi: 10.1007/s00114-011-0774-3

Leppänen, J., Seppä, P., Vepsäläinen, K. \& Savolainen, R. (2015) Genetic divergence between the sympatric queen morphs in the ant Myrmica rubra. Molecular Ecology 24, 2463-2476, doi:10.1111/mec. 13170

McInnes, D.A. \& Tschinkel, W.R. (1995) Queen dimorphism and reproductive strategies in the fire ant Solenopsis geminata (Hymenoptera: Formicidae). Behavioral Ecology and Sociobiology, 36, 367-375. doi: 10.1007/bf00177332

Meunier, J. \& Chapuisat, M. (2009) The determinants of queen size in a socially polymorphic ant. Journal of Evolutionary Biology, 22, 1906-1913. doi:

$$
\text { 10.1111/j.1420-9101.2009.01805.x }
$$

Niemelä, J., Haila, Y., Halme, E., Pajunen, T. \& Punttila, P. (1989) The annual activity cycle of carabid beetles in the southern Finnish taiga. Annales Zoologici Fennici, 26, $35-41$.

Niemelä, J., Haila, Y., Halme, E., Pajunen, T. \& Punttila, P. (1992) Small-scale heterogeneity in the spatial distribution of carabid beetles in the southern Finnish taiga. Journal of Biogeography, 19, 173-181. doi: 10.2307/2845503

Niemelä, J., Haila, Y. \& Punttila, P. (1996) The importance of small-scale heterogeneity in boreal forests: variation in diversity in forest-floor invertebrates across the succession gradient. Ecography, 19: 352-368.

O'Riain, M.J., Jarvis, J.U.M. \& Faulkes, C.G. (1996) A dispersive morph in the naked mole-rat. Nature, 380, 619-621. doi: 10.1038/380619a0

Pamilo, P., Gertsch, P., Thorén, P. \& Seppä, P. (1997) Molecular population genetics in social insects. Annual Review of Ecology and Systematics 28, 1-25.

Passera, L. \& Keller, L. (1990) Loss of mating flight and shift in the pattern of carbohydrate storage in sexuals of ants (Hymenoptera; Formicidae). Journal of Comparative Physiology B, 160, 207-211. doi: 10.1007/bf00300955 
653 Peeters, C. \& Ito, F. (2001) Colony dispersal and the evolution of queen morphology in

654

655

656

657

658

659

660

661

662

663

664

665

666

667

668

669

670

671

672

673

674

675

676

677

678

679

680

681

682

683 social Hymenoptera. Annual Review of Entomology, 46, 601-630. doi: 10.1146/annurev.ento.46.1.601

Punttila, P., Haila, Y., Pajunen, T. \& Tukia, H. (1991) Colonisation of clearcut forests by ants in the southern Finnish taiga: a quantitative survey. Oikos, 61, 250-262. doi: $10.2307 / 3545343$

Punttila, P., Haila, Y., Niemelä, J. \& Pajunen, T. (1994) Ant communities in fragments of old-growth taiga and managed surroundings. Annales Zoologici Fennici, 31, 131144.

Punttila, P., Autio, O., Kotiaho, J.S., Kotze, D.J., Loukola, O.J., Noreika, N. \& Vepsäläinen, K. (2016) The effects of drainage and restoration of pine mires on habitat structure, vegetation and ants. Silva Fennica, 50, 1462. doi: 10.14214/sf.1462

Queller, D.C. \& Goodnight, K.F. (1989) Estimating relatedness using genetic markers. Evolution, 43, 258-275. doi: 10.2307/2409206

Radchenko, A.G. \& Elmes, G.W. (2010) Myrmica ants (Hymenoptera, Formicidae) of the old world. Natura Optima Dux Foundation, Warsaw, Poland.

Roff, D.A. (1992) The evolution of life histories: theory and analysis. Chapman and Hall, New York, U.S.A.

Rosengren, R. \& Pamilo, P. (1983) Evolution of polygyny and polydomy in moundbuilding Formica ants. Acta Entomologica Fennica, 42, 65-77.

Rüppell, O. \& Heinze, J. (1999) Alternative reproductive tactics in females: the case of size polymorphism in winged ant queens. Insectes Sociaux, 46, 6-17. doi: $10.1007 / \mathrm{s} 000400050106$

Rüppell, O., Heinze, J. \& Hölldobler, B. (1998) Size-dimorphism in the queens of the North American ant Leptothorax rugatulus (Emery). Insectes Sociaux, 45, 67-77. doi: 10.1007/s000400050069

Rüppell, O., Heinze, J. \& Hölldobler, B (2001) Alternative reproductive tactics in the queen-size-dimorphic ant Leptothorax rugatulus (Emery) and their consequences for genetic population structure. Behavioral Ecology and Sociobiology, 50, 189-197. doi: $10.1007 / \mathrm{s} 002650100359$

SAS Institute Inc. (1990) SAS/STAT User's Guide, Version 6, 4th Edn. 
684 Seifert, B. (1993) Taxonomic description of Myrmica microrubra n. sp. - a social

685

686

687

688

689

690

691

692

693

694

695

696

697

698

699

700

701

702

703

704

705

706

707

708

709

710

711

712

713

714

715 parasitic ant so far known as the microgyne of Myrmica rubra (L.). Abhandlungen und Berichte des Naturkunde Museums Görlitz 67, 9-12.

Seppä, P. (1992) Genetic relatedness of worker nestmates in Myrmica ruginodis (Hymenoptera: Formicidae) populations. Behavioral Ecology and Sociobiology, 30, 253-260. doi: 10.1007/bf00166710

Seppä, P. (1994) Sociogenetic organization of the ants Myrmica ruginodis and Myrmica lobicornis: number, relatedness and longevity of reproducing individuals. Journal of Evolutionary Biology, 7, 71-95. doi: 10.1046/j.1420-9101.1994.7010071.x

Seppä, P., Sundström, L. \& Punttila, P. (1995) Facultative polygyny and habitat succession in boreal ants. Biological Journal of Linnean Society, 56, 533-551. doi: 10.1111/j.1095-8312.1995.tb01109.x

Stearns, S.C. (1992) The evolution of life histories. Oxford University Press, New York.

Stille, M. (1996) Queen/worker thorax volume ratios and nest-founding strategies in ants. Oecologia, 105, 87-93. doi: 10.1007/bf00328795

Sundström, L. (1995) Dispersal polymorphism and physiological condition of males and females in the ant Formica truncorum. Behavioral Ecology, 6, 132-139. doi: 10.1093/beheco/6.2.132

Sundström, L., Seppä, P. \&Pamilo P (2005) Genetic population structure and dispersal patterns in Formica ants - a review. Annales Zoologici Fennici, 42, 163-177.

Thornhill, R. \& Alcock, .J (1983) The evolution of insect mating systems. Harvard University Press, Cambridge, Mass.

Walin, L. \& Seppä, P. (2001) Resource allocation in the red ant Myrmica ruginodis - an interplay of genetics and ecology. Journal of Evolutionary Biology, 14, 694-707. doi: 10.1046/j.1420-9101.2001.00332.x

Wheeler, D.E. \& Martinez, T. (1995) Storage proteins in ants (Hymenoptera: Formicidae). Comparative Biochemistry and Physiology B - Biochemistry \& Molecular Biology, 112, 15-19. doi: 10.1016/0305-0491(95)00035-7

Wolf, J.I. \& Seppä, P. (2016a) Queen size dimorphism in social insects. Insectes Sociaux, 63, 25-38. doi: 10.1007/s00040-015-0445-z

Wolf, J.I. \& Seppä, P. (2016b) Dispersal and mating in a size dimorphic ant. Behavioral Ecology and Sociobiology, 70, 1267-1276. doi: 10.1007/s00265-016-2135-x 
716 Wolf, J.I. 2016 Genetic and behavioural divergence of queen size morphs in the red ant

717 Myrmica ruginodis. PhD dissertation, University of Helsinki, Helsinki, Finland 718 URN:ISBN:978-951-51-2454-8

719 Zeisset, I., Ebsen, J.R. \& Boomsma, J.J. (2005) Dinucleotide microsatellite DNA loci

720 from the ant Myrmica scabrinodis. Molecular Ecology Notes, 5, 163-164. doi:

$721 \quad 10.1111 / \mathrm{j} .1471-8286.2004 .00871 . x$ 